\title{
Subnational government and transnational networking: the rationalist logic of local level Europeanization
}

\begin{abstract}
The involvement of subnational actors in EU politics has become an increasingly recognized facet of European integration. However, this highlights an interesting puzzle: subnational authorities in unitary and centralized polities usually lack formal competence and have limited resources to engage beyond their territorial limits. Why, then, do they engage at the European level? This article addresses this question by exploring their motivations for participation in European transnational networking. These motivations are assessed against a Europeanization framework, exploring whether subnational authorities adopt the 'logic of consequentialism' or the 'logic of appropriateness' when engaging in transnational networking. The article argues that subnational authorities are rational actors, maximizing the opportunities presented by the EU without subscribing to its normative aims. In a context marked by financial pressures and Brexit, these findings provide a useful foundation for analysing the ongoing EU-local relationship, and for explaining changes to subnational authorities' approaches to European engagement.
\end{abstract}

Keywords: Europeanization; subnational government; transnational networking; EUlocal relations

\section{Introduction}

The presence of subnational authorities (SNAs) at the European Union (EU) level is increasingly recognized. This includes recognition in the Committee of the Regions, the 
presence of local and regional representative offices in Brussels (for example Rowe, 2011; Tatham, 2010, 2016) and engagement in subnational transnational networks (for example Heinelt and Niederhafner, 2008; Huggins, 2017; Kern and Bulkeley, 2009; Payre, 2010). These activities have led to a growing literature on local level Europeanization (for example Barbehön, 2016; Benz and Eberlein, 1999; de Rooij, 2002; Goldsmith, 1993, 2003, 2011; Hamedinger and Wolffhardt, 2010; Huggins, 2017; John, 2000, 2001; Kern and Bulkeley, 2009; Kettunen and Kungla, 2005; Marshall, 2005; Pflieger, 2014; Van Bever et al., 2011).

One feature of this has been SNAs' engagement in transnational networking (TN). This encompasses voluntary horizontal links between subnational actors across national borders. This activity comes in a variety of forms. A distinction can be made between informal networks of subnational officials sharing information (for example Beyers and Donas, 2014) or membership of more formalized partnerships and associations. This article focuses on the latter. This itself is marked by diversity. Some networks act as peak associations, representing broad subnational interests, while others focus on particular geographical areas or have particular policy focuses (Benington and Harvey, 1994; Ward and Williams, 1997, p. 441). Networks often include a range of non-governmental subnational actors too, such as universities or businesses. Networks' size also varies. Some are bilateral partnerships between two SNAs, while others are multilateral (Huggins, 2017; Kern, 2014, p. 115). Co-operation can also be open-ended or temporary to deliver particular projects.

While TN is indicative of the Europeanization processes affecting SNA, wider international engagement has also been witnessed. This includes engagement in global transnational networks, particularly with a focus on environmental policy such as the 
C40 cities network (for example Bouteligier, 2013; Lee, 2014), and the emergence of trans-Atlantic bilateral partnerships (for example Casson and Dardanelli, 2012).

For SNAs in unitary and centralized polities, however, engagement in TN presents an interesting puzzle. Engagement in TN is voluntary. Furthermore, these SNAs usually lack the formal competence to engage beyond their territorial limits and their budgets are often heavily constrained. These financial constraints have recently been exacerbated by the financial crisis and austerity. However, while some SNAs are reassessing their EU engagement activities as a result of this (Guderjan, 2015; Guderjan and Miles, 2016, p. 642), engagement in TN remains commonplace. Why, then, are these SNAs investing in an activity which they are not mandated to undertake, while available resources to deliver their core and statutory functions are increasingly under pressure? This article addresses this puzzle, providing an insight into what drives these SNAs to participate in TN. In doing so it advances a wider debate on the impact of local level Europeanization to change subnational behaviour by arguing SNAs are rationally driven when engaging at the European level. In context where opportunities for EU level engagement are constantly changing, this has important and timely implications for understanding the long-term impact of local level Europeanization. SNAs engage because it is in their interest, and their presence at the European level is not permanent. This article therefore offers a useful foundation for assessing ongoing changes to the EU-local relationship, as well as how SNAs are responding and adapting their European engagement activities to this context.

This article analyses the TN activities of 14 SNAs in South East England and Northern France.[1] These cases are typical of SNAs in unitary and centralized polities having relatively limited levels of independent authority and capacity to act (Hooghe et $a l ., 2016)$. While French SNAs enjoy constitutional protection whereas English SNAs 
do not, subnational actors in both polities are subject to fluctuating institutional landscapes, exemplified by the amalgamation of French régions in 2016 and a complex and inconsistent mix of Local Enterprise Partnerships, combined authorities and 'city deals' in England. They have similarly both faced budgetary pressures brought by austerity and decreased central government grants. These cases therefore allow the puzzle of why SNAs with limited formal competence to engage internationally nevertheless engage in $\mathrm{TN}$ while simultaneously facing financial pressures to deliver their core services to be addressed. Furthermore they have an established tradition of engaging in TN (Church and Reid, 1996, 1999). Between 2001 and 2011, they were involved in 302 transnational links (Huggins, 2017). As a result they have been heavily exposed to Europeanization processes over at least 30 years. These cases therefore represent a good testing ground to assess how SNAs have engaged with these processes, and whether lengthy exposure to Europeanization has affected their behaviour.

The empirical findings come from an analysis of 68 qualitative semi-structured interviews with subnational officers, councillors and others involved in TN. These participants played a direct role in their respective organizations' TN activity, including in decisions on whether to participate. Interviews were complemented with an analysis of over 100 documents produced by SNAs, largely dating between 2001 and 2011. This period captures the onset of the financial crisis, permitting an analysis into why SNAs continue to engage in $\mathrm{TN}$ despite the restrictive effect this context has on their resources.

This article firstly surveys existing research on local level Europeanization, making a distinction between rational Europeanization and sociological Europeanization as a useful framework to understand the underlying logic driving this process. The second section outlines the motivations held by SNAs for participating in 
TN. The third section assesses these motivations in detail. It finds SNA engagement in $\mathrm{TN}$ is goal orientated and driven by a desire to improve SNAs' own position and secure competitive advantage. Furthermore it is based on an assessment of the prevailing context and the outcome of a favourable cost-benefit analysis which effectively depoliticizes engagement. Engagement takes place with full awareness of its limitations. This confirms SNA engagement in TN to be rationally driven. An absence of sociological drivers reinforces this. The article concludes by considering the implications of these findings in light of contemporary developments in European politics.

\section{Local level Europeanization: rational versus sociological logics}

The concept of Europeanization has been readily applied to the subnational level (for example Barbehön, 2016; Benz and Eberlein, 1999; de Rooij, 2002; Goldsmith, 1993, 2003, 2011; Hamedinger and Wolffhardt, 2010; Huggins, 2017; John, 2000, 2001; Kern and Bulkeley, 2009; Kettunen and Kungla, 2005; Marshall, 2005; Murphy, 2007; Pflieger, 2014; Van Bever, et al., 2011). Early research on local level Europeanization focused on the extent to which SNAs had become 'Europeanized' (Goldsmith, 1993; Goldsmith and Klausen, 1997; John, 2000, 2001). While it is argued that all SNAs are affected by Europeanization, differentiation in the extent to which they have been Europeanized was observed (de Rooij, 2002; Goldsmith and Klausen, 1997; Hamedinger and Wolffhardt, 2010; John, 2001; Le Galès 2002), resulting in a 'variable geometry Europe' (Le Galès, 2002, p. 110). This is accounted for by variances in local resources and local political leadership which mediate the impact of Europeanization at the local level (de Rooij, 2002; Oikonomou, 2016; Pflieger, 2014). 
More recently, local level Europeanization research has focused on directionality. Europeanization is seen as inherently top-down. European policies, processes and practices are seen to be 'downloaded' to lower levels. Yet those affected by the pressures of Europeanization also proactively shape them. In this bottom-up conceptualization, actors 'upload' their preferences to the EU, reducing the eventual costs of 'downloading' EU policy, for example (Börzel, 2002, p. 196). Horizontal Europeanization processes are also identified (Graziano and Vink, 2013, p. 47). Here the EU provides a reference point for actors to co-operate and share policies and practices with each other.

These dynamics are present at the subnational level. While local level Europeanization can be characterized as top-down, with SNAs having to implement and comply with EU legislation and policy, the EU is seen as an opportunity structure. Through representation offices in Brussels and TN, subnational preferences are 'uploaded' to the EU (Van Bever et al., 2011, pp. 18-20). Consequently, local level Europeanization has been characterized as a co-operative process (Schultze, 2003). Additionally the role of TN to foster policy learning and transfer between SNAs illustrates the presence of horizontal Europeanization (Kern and Bulkeley, 2009; Van Bever et al., 2011).

The differentiated impact of local level Europeanization, together with the presence of bottom-up and horizontal dynamics, suggests SNAs are not passive actors in EU politics. Rather they are proactive and voluntarily engage. This leads to a question of why SNAs engage. Europeanization literature offers two potential explanations. Europeanization can follow the logic of rational choice institutionalism or sociological institutionalism (Börzel and Risse, 2003). Under rational Europeanization actors follow the logic of consequentialism. They are goal oriented, seeking to improve 
their position. Europeanization is thus a reaction to potential opportunities or constraints, and the result of a cost-benefit analysis, where the cost of becoming Europeanized is outweighed by the benefits it brings, such as additional resources, competitive advantage or reducing the costs associated with Europeanization itself (Börzel and Risse, 2003, pp. 63-65; Hamedinger and Wolffhardt, 2010, pp. 15-16). That actors seek to pursue their own interests does not preclude them working together, since there is dependence between them (Börzel, 2005, p. 52). This model sees SNAs engage with Europeanization processes because it is in their interest. Under sociological Europeanization actors follow the logic of appropriateness. Their behaviour is determined by EU rules, norms and preferences which become internalized through learning and socialization processes (Börzel and Risse, 2003, pp. 65-67; Hamedinger and Woffhardt, 2010, p. 16). As Börzel (2005, p. 54) argues, 'rather than maximizing their subjective desires, actors seek to "do the right thing"'. Here SNAs follow a 'metooism' logic (Duchacek, 1984), engaging with Europeanization processes because it is deemed appropriate.

While the utility of applying this rational-sociological model to local level Europeanization has been recognized (Hamedinger and Woffhardt, 2010), its application is limited, and the underlying logic driving SNAs' Europeanization remains unclear. Local level Europeanization is sometimes viewed as a process of change marked by the learning EU rules and norms, fitting the sociological explanation. John (2000, p. 882), for example, sees full local level Europeanization as 'a more fundamental transformation that goes beyond short-term instrumental behaviour, whereby local policy-making becomes an aspect of the EU, and European ideas and practices become transferred to the core of local decision-making'. Marshall (2005, pp. 676-677) similarly observes that English SNAs have 'adjusted to European norms of 
direct lobbying, partnership working and long-term strategic programming' resulting in localities 'revisioning' themselves in European terms. Yet there are perceived limits to sociological Europeanization at the local level. Pflieger (2014) showed participation in the EU's City-Vitality-Sustainability (CIVITAS) programme was a means to achieve pre-existing strategic goals and self-promotion. Research investigating the international activities of SNAs more broadly concurs (for example Betsill and Bulkeley, 2004; Lefèvre and d'Albergo, 2007; van der Heiden, 2010). Both processes can occur simultaneously. While SNAs may adopt a rationalist approach to Europeanization, sociological Europeanization can still take place as subnational actors are exposed to European norms (Bache, 2008, p. 158; Dąbrowski, 2012, 2013, p. 1370).

Nonetheless, empirical analysis into the rationalist and/or sociological logic driving Europeanization at the local level, and especially TN, remains limited. This article therefore addresses this gap by surveying long-term SNA engagement in TN, and informs wider debates on local level Europeanization and the role of subnational level in European integration by providing a useful foundation to understand SNAs' motives for EU engagement.

\section{Transnational networking and subnational motives}

Existing literature on subnational transnational networks reveals several functions and services they provide for their members. These include securing EU funding (for example McAleavey and Mitchell, 1994; Pflieger, 2014), lobbying EU institutions and influencing EU policy (for example Heinelt and Niederhafner, 2008; Ward and Williams, 1997), engaging in policy transfer (for example Betsill and Bulkeley, 2004; Kern and Bulkeley, 2009; Salskov-Iversen, 2006) increasing the profile of local areas (for example Payre, 2010; Phelps et al., 2002; van der Heiden, 2010) and encouraging 
inward investment and economic development (for example Heeg et al., 2003; Payre, 2010). However, while the stated purpose of transnational networks is relatively well known, little is understood about the underlying logic driving SNAs' participation, and subnational motivations for transnational engagement do not necessarily match the stated function of networks.

Three motivations stand out: obtaining funding, influencing EU policy and policy transfer. Regarding obtaining funding, SNAs saw TN as a way to find out about available funding opportunities and access support to bid under programmes regularly perceived as administratively burdensome. Networks can offer 'ready-made' transnational partnerships, which were usually a requirement for EU territorial cooperation programmes, thus reducing the effort in finding suitable partners and limiting risks associated with working with unknown partners. Regarding lobbying and influence, SNAs acknowledged the burden of EU legislation they were required to implement. While they recognized the EU was receptive to SNAs' input, they were also aware of the competitive lobbying environment present at the European level. TN here provided a means to access the EU policy process, by pooling resources and aggregating local interests, and presenting SNAs as representative and credible stakeholders in the eyes of EU policy makers. Regarding policy transfer, SNAs sought to identify and apply best practice or policy innovation. TN provided a platform for this exchange of knowledge and enabled SNAs to access best practice from abroad. TN also provided a way for innovative SNAs to 'showcase' their own best practices.

There are more general observations. Firstly, in seeking these benefits, SNAs referred to a range of contextual factors they were trying to address, such as an adverse economic climate, restricted local budgets, the impact of EU legislation and a 
competitive policy arena. In this way TN represented an 'opportunity structure' which SNAs have used to address the impact of this context and improve their overall position. Secondly, the presence of several motivations demonstrates that SNAs sought a number of simultaneous benefits from their TN activities, as opposed to any single overriding one. The diversity of motivations present in any one SNA is illustrated when examining the aims of European activity in strategic documents (Brighton and Hove City Council, 2007; Conseil Régional de Bretagne, 2011; East Sussex County Council, 2000; Kent County Council, 2007a; Southampton City Council, 2007; West Sussex County Council, 2001, 2002, 2006). Often these multiple motivations serve one another. For example, engagement in policy transfer enhances SNAs' profiles as policy innovators, which then assists in finding partners for EU-funded projects, or enhances the credibility of lobbying positions. This diversity of motivations reinforces criticisms made by some (for example John, 2000, p. 881; Kern and Bulkeley, 2009, p. 310) that existing literature on SNAs' engagement in EU politics is too heavily focused on EU funding and regional policy, or on subnational interest representation.

Thirdly, motivations vary. This was highlighted by several transnational network and Interreg staff, participants who were often in a position to observe the motivations of several SNAs at once. As argued below, this variation suggests a strategic approach to TN, where SNAs seek benefits according to their individual pre-determined strategies.

Finally, motivations for participation in TN change over time. Sometimes this occurs as a result of exposure to TN itself; the longer a SNA is involved in a network the more chance it has to be exposed to benefits beyond its original motivations to join.[2] More often, however, this occurred because of a shift in SNAs' strategic priorities, often occurring because of a change in political leadership. 


\section{Transnational networking as rationalist Europeanization}

The analysis of motivations for engagement in TN confirm the process of local level Europeanization in the SNAs studied to be rationally driven. Five features characterize this: participation is goal orientated, SNAs seek to improve their own positions and secure competitive advantage, participation is based on an assessment of the context, participation is based on a cost-benefit analysis, and there is an awareness of the limits to TN. An absence of sociological drivers, marked by two characteristics, reinforces this. Firstly SNAs ceased participation in TN when it no longer met their interests, suggesting limits to the internalization of networking behaviour and 'me-tooism' as a driver. Secondly, altruistic motives which went beyond SNAs' self-interest were not present.

\section{A goal orientated approach}

SNAs are goal oriented, participating in TN to achieve their own strategic aims. This link between a SNA's aims and the motivations behind their TN activities is confirmed when analysing strategic documents, which highlight how specific benefits of TN assist in achieving specific strategic objectives (Brighton and Hove City Council, 2007; Conseil Régional de Bretagne, 2011; East Sussex County Council, 2000; Kent County Council, 2007a; Southampton City Council, 2007; West Sussex County Council, 2001, 2002, 2006). Brighton and Hove City Council's (2007) international strategy, for example, 'aims to contribute to the delivery of the council's strategic priorities: the emphasis being on complementing existing or planned council activity'. Participants also stated their SNA's motivations were rooted in achieving their wider strategic plan. As noted by one: 'obviously we're always working towards our main council strategies and the various different strategies for different departments and business plans and so 
on'.[3] Further evidence of this is found in documentation seeking approval for participation in transnational networks. Figure 1, for example, shows how one SNA links cases of TN to specific elements of their community strategy and corporate plan. In seeking approval to participate in one EU-funded transnational project, another report noted that co-operation 'contributes to the City and Employment Skills Plan's (CESP) 2011-2014 vision, in particular to "priority three" of the plan which seeks to ensure that local residents are equipped to compete for jobs in the city's labour market' (Brighton and Hove City Council, 2011).

[FIGURE 1 HERE]

Crucially SNAs did not change their behaviour, but maintained pre-existing goals. TN was seen as an opportunity to contribute towards achieving these predetermined goals. This mirrors Pflieger's (2014) findings, which showed French cities strategically engaged in the CIVITAS programme as a means to achieve existing projects which would have been undertaken regardless.

This goal orientated approach also accounts for the differentiation in the motivations held by SNAs. As strategic objectives vary between SNAs, so their reasons for participating in transnational networks do too. In particular this affects which networks SNAs choose to engage with, as they seek to pursue specific thematic policy interests (van der Heiden, 2010, p. 132). For example, the Isle of Wight's participation in the Conference of Peripheral Maritime Regions (CPMR) and Islands Commission was motivated by their interest in coastal erosion mitigation.[4] Basse-Normandie's large agricultural sector made participation in the Association of European Regions for Products of Origin and Assembly of the European Regions Producing Fruit, Vegetables and Plants a priority.[5] The mix of urban and rural areas across South East England 
meant involvement in the Peri-Urban Regions Platform Europe network was a priority several SNAs here (SEERA, 2004, 2005).

Evidence of this policy centric approach can also be found with transnational networks which are not policy specific and appear more general purpose in nature. Such networks organized themselves into a number of thematic working groups, forums and sub-networks. Brighton and Hove, which had corporate priorities in promoting the digital economy and cultural policy, pursued its thematic interests through Eurocities' knowledge society and culture forums.[6] Hampshire was able to pursue its interest in education and environmental policy through the relevant Assembly of European Regions (AER) sub-groups.[7]

In cases where there were no pre-existing networks focused on a SNA's area of strategic interest, they often established new ones. Bretagne, for example, had a long standing interest in maritime policy, leading to their role establishing the CPMR (Wise, 2000). As explained by a French regional officer: 'there is a very strong link between Brittany and this network, because it's a maritime network and we are a maritime region'.[8] West Sussex likewise co-established the Airport Regions Conference due to the strategic importance of Gatwick Airport and aviation policy to the county.[9] Establishing new networks requires significant effort and resources (van der Heiden, 2010, p. 150), and so SNAs would only make this investment if it directly contributed to their overriding strategic objectives.

This goal orientated approach is further illustrated by cases where motivations for participation changed as a result of a shift in local priorities, usually occurring following a change in political leadership. For example, before 2005 the Isle of Wight was heavily involved in lobbying activities and policy transfer, sharing knowledge with other coastal regions on landslide and erosion issues as these were strategic priorities. 
From 2005 and the election of a new administration, their strategy shifted away from this, with more emphasis placed on obtaining funding.[10] This ultimately led to their withdrawal from the CPMR and Islands Commission, as the lobbying and policy transfer advantages these networks brought were no longer deemed important (Isle of Wight Council, 2005).

\section{Improve positions and secure competitive advantage}

SNAs' engagement in TN is characterized by their self-interest and a determination to improve their own individual positions. Indeed, the motivations outlined above all reflect SNAs' desires to secure benefits for their own organization, as opposed to contributing to wider European policy goals. While in some cases participants referred to altruistic motives, for example in sharing examples of best practice, this was due to the overriding motivation of improving SNAs' profiles by promoting themselves as a policy innovator, or, in the words of one participant, 'best in class'.[11] Indeed, it was felt that such an improved profile brought with it greater success in obtaining funding and securing economic investment as it raised awareness among key EU funders. It also improved the chances of influencing EU policy as being recognized as a policy innovator meant being regarded as an expert, which accorded credibility to the policy positions SNAs promoted. This confirms Lefèvre and d'Albergo's (2007, p. 312) speculation that 'even some apparently socially orientated international activities might actually be interpreted as motivated by economic aims'.

While TN is inherently co-operative, participants also noted that they were motivated by trying to secure competitive advantage vis-à-vis other SNAs, particularly for limited resources or opportunities such as funding and economic investment. SNAs often viewed other network members as competitors rather than partners. For example 
Brighton and Hove City Council (2008) justify participation in Eurocities by acknowledging it:

contains Belfast, Birmingham, Bradford, Bristol, Cardiff, Hull, Leeds, Liverpool, London, Manchester, Newcastle, Nottingham, Sheffield, Southampton and Sunderland. Whilst there are all potential partners they are all potential rivals economically within the UK so parity of information and influence and visibility on a European and international stage is crucial.

In obtaining funding, SNAs were aware of the competitiveness of EU programmes. Medway Council (2003), for example, highlights the need to have 'a head start over potential competitors for funds by providing information in advance'. The requirement to work with others through $\mathrm{TN}$ in order to be eligible for EU funding was similarly acknowledged. Indeed following EU enlargement in 2004 many SNAs established transnational links with counterparts in central and eastern Europe to ensure continued eligibility.[12] As one participant explained:

I could see the structural funds in Europe were gradually going to shift towards helping eastern Europe, because that's where the money was needed, and if we as a British county wanted to go on receiving we need to have links with them.[13]

The need for competitive advantage in lobbying was equally recognized, with participants highlighting the potential to be 'drowned out' by other, better resourced actors in Brussels, including other SNAs. As highlighted by one:

we're trying to make sure that the concerns of Hampshire are not forgotten. I mean I'm not remotely surprised to discover that ... councillors from 
Manchester might be popping up somewhere, they going to push for the interests of Manchester. Or Liverpool, you've got Liverpool and Southampton at war with each other over cruise terminals. Well don't be surprised at a meeting where Liverpool representatives are, they're going to push in interests of Liverpool ... We've got to be there and fight our own corner.[14]

Nevertheless, given the relatively small size and limited resources of subnational actors, there was recognition that they could not have a meaningful impact on EU policy while acting alone.

Co-operation was therefore seen as a necessary evil, offering a way for SNAs to level the playing field in this competitive environment. In this way $\mathrm{TN}$ reinforces competition between localities, rather than softening it (Pflieger, 2014, p. 333).

\section{Assessing the context, constraints and opportunities}

In all cases, subnational participation in $\mathrm{TN}$ was a reaction to a number of contextual factors which acted as potential constraints or opportunities. This manifests itself in different ways depending on the specific benefit being sought. In obtaining funding, for example, SNAs recognized the restrictive financial context in which they operated. Indeed all of the SNAs studied faced continued budget cuts as both central government grants and local tax revenues were reducing, something affecting SNAs across the EU. Nevertheless, SNAs also recognized the availability of a wide range of schemes and cooperation programmes such as Interreg and URBACT, which offered funding for projects they otherwise would not be able to afford, provided they work with partners in other European countries. In this way TN was an opportunity structure which provided SNAs with a way to address the impact of this adverse financial context and take 
advantage of EU-funded programmes. As highlighted in a Kent County Council (2011) report:

The last year has also, of course, continued to be dominated by heavy pressure on public funding and budgetary reductions within the County Council. Such domestic pressures might have made it more difficult for $\mathrm{KCC}$ to maintain an outward-looking focus and international profile. However, the contribution of EU funding to business priorities and the identification of European best-practice and collaborative working to improve performance makes this activity even more important in the current climate.

This applied beyond obtaining funding. In seeking to influence EU policy, SNAs estimated between 70 and 80 per cent of EU legislation directly impacted them (Kent County Council, 2007a; West Sussex County Council, 2006). SNAs therefore saw themselves as implementers of EU legislation, but under-represented in EU decisionmaking:

Local authorities are primarily seen as implementers and enforcers of EU policy and legislation, but in spite of this have traditionally had a weak voice in the EU decision-making process. (West Sussex County Council, 2006)

SNAs felt they were better placed to inform discussion on EU policy given their role in implementation and their propinquity to citizens. As highlighted in one report:

It is important that local government continues to be recognised as a legitimate actor in European affairs. It is the level that delivers key services 
to residents, businesses and the voluntary sectors and as such is in a favourable position to provide input to the EU institutions on how European policies and legislation work on the ground. (Isle of Wight Council, 2004)

SNAs recognized that the EU was receptive to local opinion and this presented an opportunity to become involved. Yet they equally appreciated that they were unable to have a significant impact acting individually given their limited size and resources. The EU policy arena was perceived as a competitive environment in which individual SNAs would be drowned out by other well-resourced corporate and non-governmental interests, in addition to other local and regional actors.

\section{Cost-benefit analyses and depoliticization}

SNA engagement in TN is based on a favourable cost-benefit analysis. This is most evident with the funding motivation, where the potential gain of finance through EU grants was seen as far greater than the costs associated with networking. As one councillor noted:

It's probably a total cost of $£ 100,000$ of our membership of groups and sending people to various delegations ... but we want to be sure that we're receiving in return ... more than that, and normally it's operating at many many times. It's not unusual for us to be collecting something like $£ 2$ million a year or so, something like that, in grants from various European projects.[15]

Indeed, another remarked that if they stopped investing in TN their authority would be losing over £10million a year in the benefits it brought.[16] Committee documentation approving engagement in TN also rationalized participation in simple cost-benefit 
terms, as illustrated in Figure 2.

\section{[FIGURE 2 HERE]}

This cost-benefit calculation applied to motivations beyond obtaining funding. In lobbying SNAs recognized the burden and costs associated with implementing EU legislation and so sought to lower these costs. Influencing EU policy development through TN was thus seen as a low cost method for achieving this. This fits with Börzel's (2002, p. 196) explanation of Europeanization where uploading local policy preferences can be regarded as 'an effective strategy to maximize the benefits and minimize the costs of European policies'. Indeed, participants felt that if SNAs failed to influence the EU, policy would ultimately be detrimental for them, particularly if they disagreed with the policy in the first place. As one explained:

If you look at legislation, often it's gold-plated, so bells and whistles get added onto things. If you don't want those bells and whistles on there, if you don't even want the piece of legislation in the first place, then you have to make your voice heard and explain why that is.[17]

In undertaking policy transfer SNAs again recognized the potential savings and efficiencies that could be found by applying lessons from abroad. In the words of one councillor, 'you could suddenly wake up to all sorts of potential ideas and cost savings'.[18] Again, this emphasizes that SNAs are undertaking a cost-benefit analysis when deciding to engage in $\mathrm{TN}$; the cost of participation is outweighed by the efficiencies and financial savings gained by applying best practice techniques leant through policy transfer.

In this way participation in $\mathrm{TN}$ became depoliticized. Local officials perceived the level of funding which could be obtained, or the savings which could be realized, to 
be so great that it overrode councillors' political views on TN, or indeed the EU more generally. As one noted:

I would generally say overall a Conservative administration ... would probably take the view that Europe was something that existed. They didn't particularly want to deal with it, but if there was money to be had they would have it.[19]

Councillors themselves referred to the 'pragmatic approach' they took to TN, and that party politics was absent from the debate.[20] This pragmaticism explains why SNAs were able to co-operate despite the sometimes radically different political ideologies held by their respective leaders and administrations. Indeed, co-operation was more likely to be hindered by differences in bureaucratic and working cultures. Party political differences, be they internal or external to a SNA, were rarely a barrier.[21]

\section{Awareness of limitations of transnational networking}

In undertaking their cost-benefit analysis, SNAs were aware of the limitations to TN. For each of the potential benefits sought participants provided words of caution. In seeking to obtain funding, for example, SNAs were mindful of the significant upfront investment required to put together a bid and the onerous nature of applying for and managing EU grants (East Sussex County Council, 2000; Kent County Council, 2007b, 2010). SNAs would only pursue it if the likely benefits, financial or otherwise, would make the effort of administration and meeting eligibility criteria worth undertaking. While SNAs were motivated to participate in TN because of the lobbying and policy transfer benefits, they were equally aware of how such benefits were hard to quantify, and that success in these areas was not guaranteed. Again, this supports the rationalist 
account. SNAs were willing to engage in $\mathrm{TN}$, but recognized the limits and would only participate if they benefits made the effort and risk worthwhile.

\section{Absence of sociological drivers}

The analysis reveals limited evidence of sociological drivers motivating participation in TN. There was evidence to suggest behaviour gradually changed as time was spent participating in transnational networks. As noted, SNAs seeking to obtain funding discovered other benefits such as policy transfer, for example. However, any internalization of norms was limited, and once engaged in $\mathrm{TN}$, future participation was not guaranteed. This is confirmed by the fact that when TN no longer met or even threatened SNAs' interests, they withdrew or altered their activity accordingly. Several examples illustrate this. West Sussex left the AER as it felt the network was not adequately representing its voice in Europe (West Sussex County Council, 2000). Hampshire left the CPMR in 2012 as it found out a number of other SNAs in the network had not paid their membership fees but were still benefiting from membership. In this case Hampshire felt it was disadvantaged by subsidizing membership for other non-paying regions, so left.[22] Hampshire and Basse-Normandie began working on divergent policy areas and consequently had different priorities. This meant their bilateral transnational link stagnated, as opportunities for policy transfer became limited.[23]

Additionally, motivations which went beyond SNAs' self-interest were rarely present. Even where they were, such motivations were supplementary. Only two participants referred to TN as a contribution to the wider European integration process.[24] Its role to secure peace in Europe was only mentioned by one participant.[25] Similarly, only one participant explicitly referred to the role of $\mathrm{TN}$ in 
making their SNA become more 'European'.[26] While many SNAs used TN to enhance their profile and promote themselves as 'European' or 'international' actors, this was a strategy to secure other benefits, such as economic investment, influence or funding. Consequently there is limited evidence to suggest SNAs followed the logic of appropriateness when participating in TN.

\section{Conclusion}

Engagement in TN is one way local level Europeanization manifests itself. However, recognizing participation in EU engagement activities is voluntary, questions are raised about what drives SNAs in unitary and centralized polities to undertake this activity when they lack the formal competence to do so and face financial constraints limiting resources available. This article addressed this by investigating the underlying logic driving local level Europeanization processes and engagement in TN. Europeanization literature offers two potential explanations. On the one hand actors follow the logic of consequentialism, pursuing their interests and engaging with Europeanization processes based on cost-benefit analyses (rational Europeanization). On the other hand actors follow the logic of appropriateness, engaging with Europeanization processes because it is deemed appropriate to do so (sociological Europeanization) (Börzel and Risse, 2003; Hamedinger and Woffhardt, 2010).

The article finds engagement in TN among the SNAs studied is rationally driven. There are five aspects to this. Firstly, SNAs were goal orientated. Participation was linked to pre-existing strategic objectives and SNAs did not change their priorities to ensure a fit with TN. Secondly, SNAs sought to improve their position versus others who were competing for limited funding and opportunities for policy influence and economic investment. Thirdly, SNAs' participation was in response to an assessment of 
the prevailing context and the constraints and opportunities this produced. Fourthly, participation followed a positive cost-benefit analysis, where the costs of engagement were perceived to be lower than the benefits gained. This depoliticized TN and decisions to participate were marked by pragmaticism. Fifthly, SNAs were aware of the limits to what TN could achieve. Additionally, there was an absence of sociological drivers. Motives which went beyond self-interest were rarely present, and, crucially, participation did not become an internalized norm. Indeed, participation ceased where SNAs felt it no longer met their interests.

In the cases studied, then, the overall picture is one where SNAs follow the logic of consequentialism, rather than the logic of appropriateness. While this article has focused on 14 SNAs, similar rationalist behaviour in TN engagement has been observed elsewhere (Pflieger, 2014; van der Heiden, 2010). This also corroborates research investigating broader international engagement activities undertaken by SNAs, showing they make deliberate decisions to get involved based on local circumstances, rather than being 'mere leaves in the wind of internationalisation' (Lefevre and d'Albergo, 2007, p. $317)$.

These findings have two implications for understanding local level Europeanization and the wider EU-local relationship. Firstly, regarding the rationalistsociological models of local level Europeanization, the findings suggest SNAs are driven by a rationalist logic, rather than a normative one. While the EU offers opportunities for European engagement, SNAs make their own decisions about whether to take advantage of them. SNAs are not compelled to participate in TN and only do so based on their pre-determined goals and if the benefits are perceived to outweigh the costs. This partly explains the differentiation of SNAs' engagement at the European level. Priorities and resources vary between individual SNAs, so their level of 
engagement will too. This points future research on local level Europeanization, and SNAs' broader international engagement activities, to focus on SNAs themselves, as locally held motives and resources, and local context, are important factors in whether SNAs engage at the EU level.

Secondly, while the presence of SNAs at the EU level is increasingly recognized, the findings suggest their perpetual involvement is not guaranteed. Rather SNAs' engagement is only assured while it remains in their interest. The cases of disengagement from $\mathrm{TN}$ revealed in this article emphasize this. This becomes important at a time when both SNAs' resources and the opportunities available to them are marked by uncertainty. Budgetary pressures have already led SNAs to reassess and, in some cases, cease EU engagement activities (Guderjan, 2015, p. 944; Guderjan and Miles, 2016, p. 642). Brexit represents another area of uncertainty likely to affect local level Europeanization processes. This does not necessarily mean SNAs' engagement in $\mathrm{TN}$, or at the EU level more generally, will cease. Examples of Swiss SNAs participating in European TN show how EU membership is not a prerequisite, provided opportunities for engagement are available and SNAs feel it is worthwhile (van der Heiden, 2010). Furthermore, examples of broader international engagement undertaken by SNAs show that $\mathrm{TN}$ is increasingly global in nature and not exclusive to the EU (Bouteligier, 2013; Lee, 2014).

Overall these findings have broader significance beyond the cases studied and beyond local level Europeanization. SNAs are subject to increasingly transformative processes. This not only includes the impact of Europeanization, but also wider trends such as territorial rescaling and the emergence of global networked spaces. This article shows that rather than being passive actors responding to these transformative processes, SNAs are actively shaping them. 


\section{Endnotes}

1. These cases represent the highest level of directly elected subnational government. They are Kent County Council, Medway Council, East Sussex County Council, Brighton and Hove City Council, West Sussex County Council, Hampshire County Council, Portsmouth City Council, Southampton City Council and the Isle of Wight Council in South East England, and the regional councils of Nord-Pas de Calais, Picardie, Haute-Normandie, Basse-Normandie and Bretagne in Northern France. Fieldwork was conducted before the amalgamation of French régions in 2016.

2. Interview with transnational network staff, July 2012 (Int. 23).

3. Interview with English local officer, May 2012 (Int. 24).

4. Interviews with English local officer, May 2012, and former English local officer, May 2012 (Int. 08; Int. 09).

5. Interview with French regional officer, July 2012 (Int. 44).

6. Interview with English local officer, May 2012 (Int. 12).

7. Interview with English local officer, September 2012 (Int. 45).

8. Interview with French regional officer, August 2012 (Int. 36).

9. Interview with multilateral network staff, July (Int. 09).

10. Interviews with English local officers, May 2012 and August 2012 (Int. 08; Int. 29; Int. 51).

11. Interview with English local officer, July 2012 (Int. 14).

12. Bilateral agreements between for example Conseil régional de Bretagne and Województwo Wielkopolskie dated 2005, retrieved from http://www.bretagne.bzh/jcms/c_13544/cooperation-internationale-et-reseaux, between East Sussex County Council and Veszprém Megye Önkormányzata data 
1996, retrieved from http://www.sussexineurope.org/leweslinks/accord.htm, and between Kent County Council and Bács-Kiskun County General Assembly dated 2004, retrieved through personal communication.

13. Interview with former English local official, June 2012 (Int. 34).

14. Interview with English councillor, April 2012 (Int. 01).

15. Interview with English councillor, April 2012 (Int. 01).

16. Interview with English councillor, May 2012 (Int. 05).

17. Interview with English local officer, July 2012 (Int. 11).

18. Interview with English councillor, April 2012 (Int. 02).

19. Interview with English local officer, May 2012 (Int. 15).

20. Interviews with English councillors, April 2012, May 2012 and November 2012 (Int. 01; Int. 05; Int. 67).

21. Interview with English local officer, July 2012 (Int. 21).

22. Interview with English councillor, July 2012 (Int. 25).

23. Interview with French regional officer, August 2012 (Int. 37).

24. Interviews with English councillor, April 2012, and transnational network staff, December 2012 (Int. 02; Int. 70).

25. Interview with Local Government Association representative, April 2012 (Int. 03).

26. Interview with French regional officer, August 2012 (Int. 36).

\section{References}

Bache, I. (2008) Europeanization and Multilevel Governance: Cohesion Policy in the European Union and Britain (Lanham: Rowman and Littlefield).

Barbehön, M. (2016) 'Europeanisation as discursive processes: Urban constructions of Europe and the local implementation of EU directives'. Journal of European Integration, Vol. 38, No. 2, pp. 163-177. 
Benz, A. and Eberlein, B. (1999) 'The Europeanization of regional polities: patterns of multi-level governance'. Journal of European Public Policy, Vol. 6, No. 2, pp. $329-348$.

Betsill M. M. and Bulkeley, H. (2004) 'Transnational networks and global environmental governance: The Cities for Climate Change Protection program'. International Studies Quarterly, Vol. 48, No. 2, pp. 471-493.

Beyers, J. and Donas, T. (2014) 'Inter-regional networks in Brussels: Analyzing the information exchanges among regional offices'. European Union Politics, Vol. 15, No. 4, pp. 547-571.

Börzel, T. A. (2002) 'Pace-setting, foot-dragging, and fence-sitting: Member state responses to Europeanization'. Journal of Common Market Studies, Vol. 40, No. 2, pp. 193-214.

Börzel, T. A. and Risse, T. (2003) 'Conceptualizing the domestic impact of Europe'. In K. Featherstone and C. M. Radaelli (eds) The Politics of Europeanization (Oxford: Oxford University Press), pp. 57-80.

Bouteligier, S. (2013) Cities, Networks, and Global Environmental Governance: Spaces of Innovation, Places of Leadership (Abingdon: Routledge).

Brighton and Hove City Council (2007) A European \& international strategy for Brighton \& Hove City Council: 2007-2013. Available at «http://www.brightonhove.gov.uk/index.cfm/request=b1000147».

Brighton and Hove City Council (2008) Application for membership of Eurocities (Culture, Recreation and Tourism Cabinet Member Meeting, 16 October 2008). Available at «http://present.brightonhove.gov.uk/mgConvert2PDF.aspx?ID=5187». 
Brighton and Hove City Council (2011) Application for the Interreg IVa called "Supporting Young and Unemployed People in Port Cities" (Planning, Employment, Economy and Regeneration Cabinet Member Meeting, 3 November 2011). Available at «http://present.brightonhove.gov.uk/mgConvert2PDF.aspx?ID=34363».

Casson, R. and Dardanelli, P. (2012) 'Local government paradiplomacy in the UK: The case of the Kent-Virginia project'. Local Government Studies, Vol. 38, No. 5, pp. 599-614.

Church, A. and Reid, P. (1996) 'Urban power, international networks and competition: The example of cross-border cooperation'. Urban Studies, Vol. 33, No. 8, pp. $1297-1318$.

Church, A. and Reid, P. (1999) 'Cross-border co-operation, institutionalization and political space across the English Channel'. Regional Studies, Vol. 33, No. 7, pp. 643-655.

Conseil régional de Bretagne (2011) Mission IX - Pour le développement des actions européenes \& international: Projet de budget primitif 2011. Available at «http://www.bretagne.fr/internet/jcms/c_13544/cooperation-internationale-etreseaux».

Dąbrowski, M. (2012) 'Shallow or deep Europeanisation? The uneven impact of EU cohesion policy on the regional and local authorities in Poland'. Environment and Planning C: Governance and Policy, Vol. 30, No. 4, pp. 730-745.

Dąbrowski, M. (2013) 'Europeanizing sub-national governance: Partnership in the implementation of European Union structural funds in Poland'. Regional Studies, Vol. 47, No. 8, 1363-1374. 
de Rooij, R. (2002) 'The impact of the European Union on local government in the Netherlands'. Journal of European Public Policy, Vol. 9, No. 3, pp. 447-467. East Sussex County Council (2000) European Strategy 2000/2006 (Cabinet Committee, 4 July 2000). Available at «http://www.eastsussex.gov.uk/yourcouncil/agendasreportsminutes/cabinet/repo rts/European\%20Strategy\%202000\%20-\%202006.pdf».

Goldsmith, M. (1993) 'The Europeanisation of local government'. Urban Studies, Vol. 30, No. 4-5, pp. 683-699.

Goldsmith, M. (2003) 'Variable geometry, multilevel governance: European integration and subnational government in the new millennium'. In K. Featherstone and C. M. Radaelli (eds) The Politics of Europeanization (Oxford: Oxford University Press), pp. 112-133.

Goldsmith, M. (2011) 'Twenty years on: The Europeanization of local government'. In E. Van Bever, H. Reynaert and K. Steyvers (eds) The Road to Europe: Main Street or Backward Alley for Local Governments in Europe? (Brugge: Vanden Broele), pp. 13-29.

Goldsmith, M. and Klausen, K. K. (eds) (1997) European Integration and Local Government (Cheltenham: Edward Elgar).

Graziano, P. R. and Vink, M. P. (2013) 'Europeanization: Concept, theory, and methods'. In S. Bulmer and C. Lequesne (eds) The Member States of the European Union, $2^{\text {nd }}$ edn, (Oxford: Oxford University Press), pp. 31-54.

Guderjan, M. (2015) 'Theorising European integration of local government - Insights from the fusion approach'. Local Government Studies, Vol. 41, No. 6, pp. 937955. 
Guderjan, M. and Miles, L. (2016) 'The fusion approach - Applications for understanding local government and European integration'. Journal of European Integration, Vol. 38, No. 6, pp. 637-652.

Hamedinger, A. and Wolffhardt, A, (2010) 'Understanding the interplay between Europe and cities: frameworks and perspectives'. In A. Hamedinger and A. Wolffhardt (eds) The Europeanization of Cities: Policies, Urban Change and Urban Networks (Amsterdam: Techne Press), pp. 9-39.

Heeg, S., Klagge, B. and Ossenbrügge, J. (2003) 'Metropolitan cooperation in Europe: Theoretical issues and perspectives for urban networking'. European Planning Studies, Vol. 11, No. 2, 139-153.

Heinelt, H. and Niederhafner, S. (2008) 'Cities and organized interest intermediation in the EU multi-level system'. European Urban and Regional Studies, Vol. 15, No. 2, pp. 173-187.

Hooghe, L., Marks, G., Schakel, A. H., Chapman-Osterkatz, S., Niedzwiecki, S. and Shair-Rosenfield, S. (2016) Measuring regional authority. Volume I: a postfunctionalist theory of governance (Oxford: Oxford University Press).

Huggins, C. (2017) 'Subnational transnational networking and the continuing process of local-level Europeanization'. European Urban and Regional Studies, prepublished online.

Isle of Wight Council (2004) Update on Activities of the Hampshire, Isle of Wight, West Sussex Brussels Office (Economic Development, Planning, Tourism and Leisure Services Select Committee, 8 January 2004). Available at «http://www.iwight.com/council/committees/Mod-Econmic/8-104/Paper\%20B.htm». 
Isle of Wight Council (2005) Proposed withdrawal from the Hampshire, Isle of Wight and West Sussex Brussels office and from the Conference of Peripheral Maritime Regions (Cabinet, 11 October 2005). Available at «http://www.iwight.com/council/committees/cabinet/11-10-05/agenda.htm».

John, P. (2000) 'The Europeanisation of sub-national governance'. Urban Studies, Vol. 37, No. 5-6, pp. 877-894.

John, P. (2001) Local Governance in Western Europe (London: SAGE Publications). Kent County Council (2007a) KCC international activities report 2006/7 (Cabinet, 3 December 2007). Available at «http://democracy.kent.gov.uk/ieListDocuments.aspx?CId=115\&MID=2378».

Kent County Council (2007b) International Agenda - European Affairs (Corporate Policy Overview Committee, 26 April 2007). Available at «http://democracy.kent.gov.uk/ieListDocuments.aspx?CId=158\&MID=2363».

Kent County Council (2010) International Affairs Group Update (Corporate Policy Overview and Scrutiny Committee, 8 April 2010). Available at «http://democracy.kent.gov.uk/ieListDocuments.aspx?CId=158\&MID=2994».

Kent County Council (2011) KCC international activities annual report 2010 - 11 (Corporate Policy Overview and Scrutiny Committee, 6 July 2011). Available at «http://democracy.kent.gov.uk/ieListDocuments.aspx?CId=158\&MID=3478».

Kern, K. (2014) 'Climate governance in the European Union multilevel system: The role of cities'. In I. Weibust and J. Meadowcroft (eds) Multilevel environmental governance: Managing water and climate change in Europe and North America (Cheltenham: Edward Elgar), pp. 111-130. 
Kern, K. and Bulkeley, H. (2009) 'Cities, Europeanization and multi-level governance: Governing climate change through transnational municipal networks'. Journal of Common Market Studies, Vol. 47, No. 2, pp. 309-332.

Kettunen, P. and Kungla, T. (2005) 'Europeanization of sub-national governance in unitary states: Estonia and Finland'. Regional and Federal Studies, Vol. 15, No. 3, pp. 353-378.

Lee, T. (2014) Global Cities and Climate Change: The Translocal Relations of Environmental Governance (Abingdon: Routledge).

Lefèvre, C. and d'Albergo, E. (2007) 'Why cities are looking abroad and how they go about it'. Environment and Planning C: Government and Policy, Vol. 25, No. 3, pp. 317-326.

Le Galès, P. (2002) European Cities: Social Conflicts and Governance (Oxford: Oxford University Press).

Marshall, A. (2005) 'Europeanization at the urban level: Local actors, institutions and the dynamics of multi-level interaction'. Journal of European Public Policy, Vol. 12, No. 4, pp. 668-686.

McAleavey, P. and Mitchell, J. (1994) 'Industrial regions and lobbying in the structural funds reform process'. Journal of Common Market Studies, Vol. 32, No. 2, pp. 237-248.

Medway Council (2003) Review of Brussels Office Representation (Regeneration and Community Overview and Scrutiny Committee, 1 April 2003). Available at «http://democracy.medway.gov.uk/Data/Regeneration\%20\&\%20Community\%2 0Overview\%20and\%20Scrutiny\%20Committee/20030401/Agenda/Report\%20( Agenda\%20item\%205)\%203.pdf». 
Oikonomou, G. (2016) 'Bypassing a centralized state: The case of the Greek subnational mobilization in the European Union'. Regional and Federal Studies, Vol. 26, No. 1, pp. 73-94.

Payre, R. (2010) 'The importance of being connected: City networks and urban government: Lyon and Eurocities (1990-2005)'. International Journal of Urban and Regional Research, Vol. 34, No. 2, pp. 260-280.

Pflieger, G. (2014) 'The local politics of Europeanization: A study of French cities' approaches to participation in the CIVITAS programme'. European Urban and Regional Studies, Vol. 21, No. 3, pp. 331-344.

Phelps, N. A., McNeill, D. and Parsons, N. (2002) 'In search of a European edge urban identity: Trans-European networking among edge urban municipalities'. European Urban and Regional Studies, Vol. 9, No. 3, pp. 211-224.

Rowe, C. (2011) Regional Representations in the EU: Between Diplomacy and Interest Mediation (Basingstoke: Palgrave Macmillan).

Salskov-Iversen, D. (2006) 'Learning across borders: The case of Danish local government'. International Journal of Public Sector Management, Vol. 19, No. 7, pp. 673-686.

Schultze, C. J. (2003) 'Cities and EU governance: Policy-takers or policy-makers?'. Regional and Federal Studies, Vol. 13, No. 1, pp. 121-147.

SEERA (2004) Peri-Urban Regions PLatform Europe: A Call for Europe's Regional and Rural Policy Agenda: Short Note to the Joint Europe Committee (Joint Europe Committee, 30 September 2004). Available at «http://www.seeda.org.uk/european_initiatives/joint_europe_committee/Meeting s/Minutes/September2004.asp». 
SEERA (2005) Update on the Dynamo Regions Network (Joint Europe Committee, 22 July 2005). Available at «http://www.seera.org.uk/european_initiatives/joint_europe_committee/Meeting s/Minutes/July2005.asp».

Southampton City Council (2007) Corporate report on European and international activities (Cabinet, 5 February 2007). Available at «http://www.southampton.gov.uk/modernGov/CeListDocuments.aspx?Committ eeId=126\&MeetingId=453\&DF=05\%2f02\%2f2007\&Ver=2».

Tatham, M. (2010) “'With or without you'? Revisiting territorial state-bypassing in EU interest representation'. Journal of European Public Policy, Vol. 17, No. 1, pp. 76-99.

Tatham, M. (2016) With, Without, or Against the State? How European Regions Play the Brussels Game (Oxford: Oxford University Press).

Van Bever, E., Reynaert. H. and Steyvers, K. (eds) (2011) The Road to Europe: Main Street or Backward Alley for Local Governments in Europe? (Brugge: Vanden Broele).

van der Heiden, N. (2010) Urban Foreign Policy and Domestic Dilemmas: Insights from Swiss and EU City-Regions (Colchester: ECPR Press).

Ward, S. and Williams, R. (1997) 'From hierarchy to networks? Sub-central government and EU urban environment policy'. Journal of Common Market Studies, Vol. 35, No. 3, pp. 439-464.

West Sussex County Council (2000) European regional association (Cabinet Member for Strategic Environmental Services, 6 September 2000). Available at «http://www.westsussex.gov.uk/cs/mis/1010env33.pdf». 
West Sussex County Council (2001) Strategy for securing European funding (Cabinet, 6 November 2001). Available at «http://www.westsussex.gov.uk/cs/cabinet/cab061101I4.pdf».

West Sussex County Council (2002) West Sussex County Council European strategy 2002 - 2004 (Resources, Information and Liaison Services Select Committee, 11 September 2002). Available at «http://www.westsussex.gov.uk/cs/committee/rils/rils1109I5.pdf».

West Sussex County Council (2006) Corporate Europe strategy 2006 - 2009 (Policy and Resources Select Committee, 10 May 2006). Available at «http://www.westsussex.gov.uk/cs/committee/PR/pr100506i7.pdf».

Wise, M. (2000) 'The Atlantic Arc: Transnational European reality or regional mirage?'. Journal of Common Market Studies, Vol. 38, No. 5, pp. 865-890. 
Figure 1: Example of aligning transnational networks to strategic priorities

(Southampton City Council, 2007)

\begin{tabular}{|c|c|c|c|c|c|c|}
\hline $\begin{array}{l}\text { PROJECT or } \\
\text { INITIATIVE }\end{array}$ & $\begin{array}{l}\text { EXTERNAL } \\
\text { FUNDING }\end{array}$ & PARTNERS & $\begin{array}{l}\text { SOUTHAMPT } \\
\text { ON CITY } \\
\text { COUNCIL } \\
\text { CONTACT }\end{array}$ & DESCRIPTION & $\begin{array}{c}\text { COMMUNITY } \\
\text { STRATEGY - } \\
\text { KEY } \\
\text { CHALLENGE }\end{array}$ & $\begin{array}{l}\text { CORPORATE } \\
\text { PRIORITIES }\end{array}$ \\
\hline $\begin{array}{l}\text { NEW EPOC - } \\
\text { Renewing the } \\
\text { Economic } \\
\text { Prosperity of } \\
\text { Port Cities }\end{array}$ & $£ 280,000$ & $\begin{array}{l}\text { Southampton City Council } \\
\text { and partners in Bilbao, } \\
\text { Bremen, Cherbourg, Gijon, } \\
\text { Kaliningrad, Pasaia, Patras, } \\
\text { Taranto, Trieste }\end{array}$ & Helen Dineen & $\begin{array}{l}£ 280,000 \text { extension funding for } \\
12 \text { months was gained June 2006 } \\
\text { (project originally began in 2003). } \\
\text { The project has identified good } \\
\text { practices in port city development } \\
\text { and produced an audit of } \\
\text { Southampton \& other port cities. } \\
\text { Specific outputs include an online } \\
\text { cultural heritage exhibition, } \\
\text { relaunch of Port City Futures (port } \\
\text { partnership), and forthcoming } \\
\text { work on cruise/tourism } \\
\text { development }\end{array}$ & $\begin{array}{l}\text { Raising } \\
\text { competitiveness } \\
\text { \& increasing } \\
\text { prosperity, } \\
\text { Improving \& } \\
\text { enhancing the } \\
\text { city's cultural } \\
\text { experience }\end{array}$ & $\begin{array}{l}\text { Tackling } \\
\text { Deprivation and } \\
\text { Inequalities }\end{array}$ \\
\hline $\begin{array}{l}\text { Cities Regain } \\
\text { Image \& } \\
\text { Identity (CRII) - } \\
\text { Supporting } \\
\text { Older People }\end{array}$ & $£ 5,600$ & $\begin{array}{l}\text { Hagen, Bristol, Leeds, } \\
\text { Bruges, Kaiserslautern, } \\
\text { Leverkusen, Rotterdam }\end{array}$ & Maite San Juan & $\begin{array}{l}\text { This seed money for SCC has } \\
\text { been awarded to discuss the } \\
\text { potential between the existing } \\
\text { partnership for a new project on } \\
\text { addressing demographic change. } \\
\text { The CRII project has, since 2004, } \\
\text { already supported work to } \\
\text { develop a coherent identity and } \\
\text { image with which current } \\
\text { businesses can identify and to } \\
\text { which new business will be } \\
\text { attracted. } £ 440,000 \text { EU funding } \\
\text { has been invested in } \\
\text { Southampton for branding/ } \\
\text { communications (Liz Kite) and } \\
\text { improved signage/ streetscape } \\
\text { (lan Rothwell - Legible Cities). }\end{array}$ & $\begin{array}{l}\text { Improving } \\
\text { educational } \\
\text { attainment, skills } \\
\text { \& overcoming } \\
\text { barriers to } \\
\text { employment } \\
\text { Raising } \\
\text { competitiveness } \\
\text { \& increasing } \\
\text { prosperity } \\
\text { Improving \& } \\
\text { enhancing the } \\
\text { city's cultural } \\
\text { experience }\end{array}$ & $\begin{array}{l}\text { Promoting } \\
\text { Independent } \\
\text { Living } \\
\text { Tackling } \\
\text { Deprivation and } \\
\text { Inequalities } \\
\text { Improving the } \\
\text { street scene } \\
\text { and the } \\
\text { environment }\end{array}$ \\
\hline
\end{tabular}

Figure 2: (Example of funding results represented in cost-benefit terms (Kent County

Council, 2007b)

\section{Costs / Benefits}

\begin{tabular}{|c|c|c|c|}
\hline Directorate & Unit / Project & Costs (£m p/a) & $\begin{array}{c}\text { Financial Benefits } \\
\text { (£m p/a) }\end{array}$ \\
\hline $\begin{array}{c}\text { Adult Social Services \& } \\
\text { Communities }\end{array}$ & $\begin{array}{c}\text { International } \\
\text { Perspectives Unit }\end{array}$ & 0.07 & $£ 20 \mathrm{~m}$ \\
\hline $\begin{array}{c}\text { Chief Executive's } \\
\text { Department }\end{array}$ & $\begin{array}{c}\text { European Affairs } \\
\text { Group }\end{array}$ & 0.321 & $£ 2.1 \mathrm{~m}$ \\
\hline $\begin{array}{c}\text { Children, Families \& } \\
\text { Education }\end{array}$ & $\begin{array}{c}\text { International } \\
\text { Development Unit }\end{array}$ & 0.08 & (to be confirmed) \\
\hline $\begin{array}{c}\text { Environment \& } \\
\text { Regeneration }\end{array}$ & Kent/Virginia & $0.315\left({ }^{*} 2007\right)$ & (to be confirmed) \\
\hline & Smithsonian & $0.225\left({ }^{*} 2007\right)$ & $£ 100 \mathrm{k}$ \\
\hline TOTALS & PASCAL & 0.058 & $£ 24.3 \mathrm{~m}$ \\
\hline
\end{tabular}

* Time limited - Costs 2005-2007 